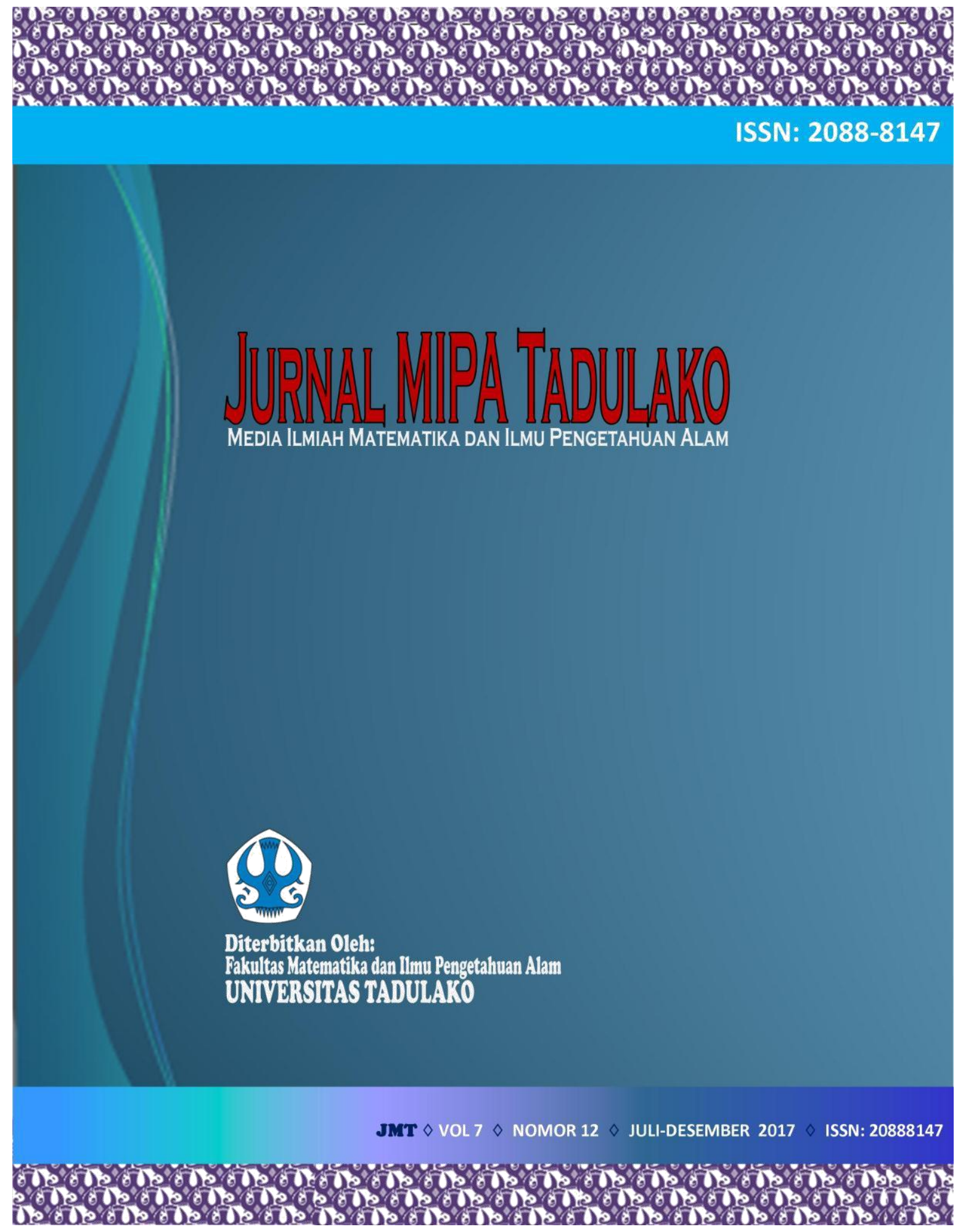




\section{JURNALLIPATADULAKO \\ Media Ilmiah Matematika dan Imu Pengetahuan Alam}

Volume 7, Nomor 2, Juli-Desember 2017

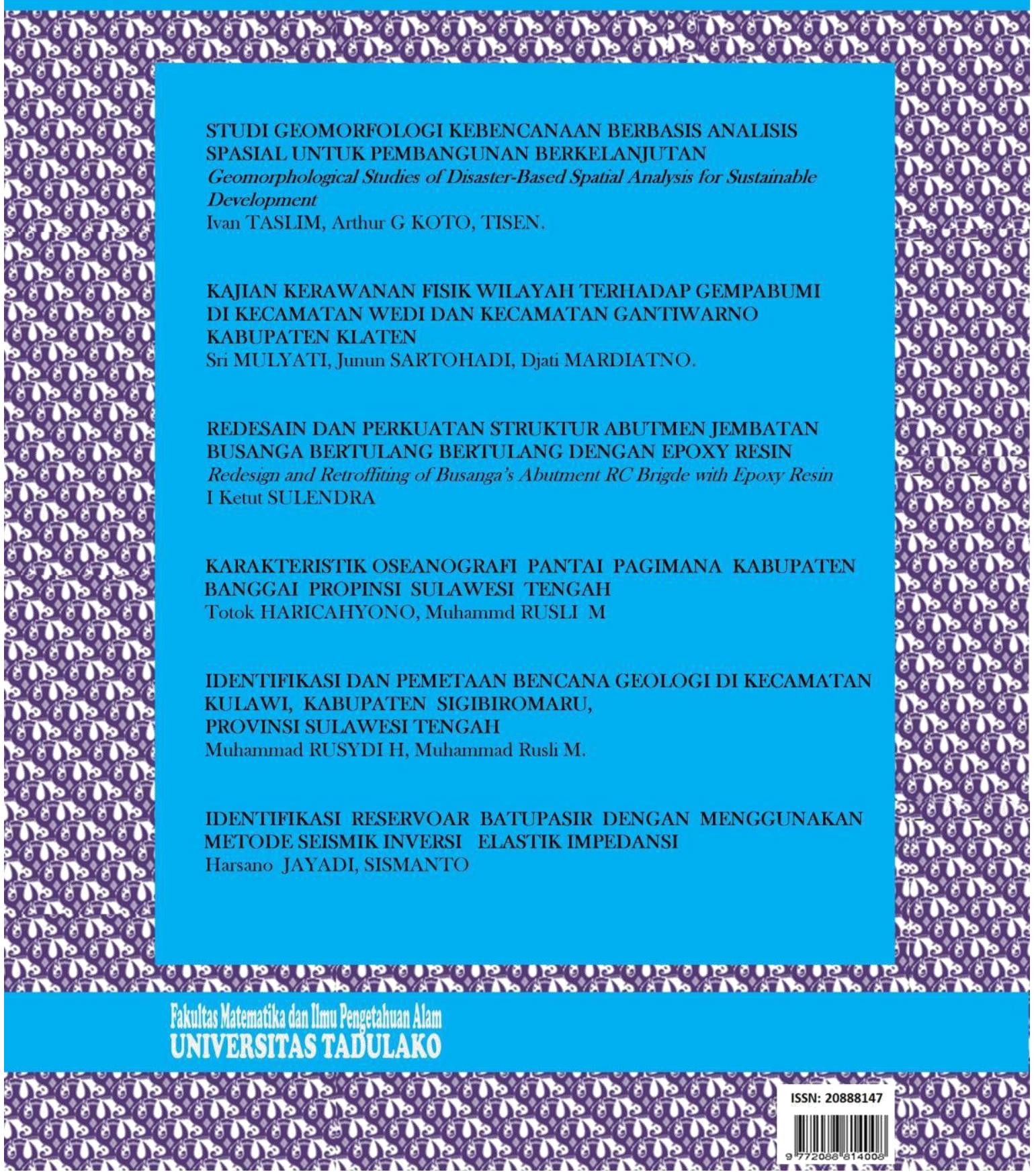




\title{
STUDI GEOMORFOLOGI KEBENCANAAN BERBASIS ANALISIS SPASIAL UNTUK PEMBANGUNAN BERKELANJUTAN
}

\author{
Ivan Taslim 1 , Arthur G. Koto', Tisen ${ }^{3}$ \\ 1,2,3 Program studi Geografi Universitas Muhammadiyah Gorontalo \\ Email:ivantaslim@umgo.ac.id
}

\begin{abstract}
ABSTRAK
Sistem pembangunan berkelanjutan di Indonesia harus berbasis mitigasi bencana. Penelitian ini bertujuan untuk menganalisa aspek-aspek geomorfologi secara spasial sebagai tahap mitigasi bencana, yaitu mengidentifikasi potensi dan kerentanan kebencanaan yang dapat ditimbulkan pada daerah Leato (Kelurahan Leato utara dan Leato selatan) pada Kecamatan Dumbo Raya Kotamadya Gorontalo. Aspek-aspek geomorfologi yang dikaji secara spasial menggunakan perangkat lunak Sistem Informasi Geografis (SIG) Global Mapper v12 dan ArcGIS v10.3. Analisa geomorfologi di lokasi penelitian didapatkan bahwa daerah tersebut memiliki morfografi wilayah pesisir hingga perbukitan terjal dengan ketinggian rata-rata $200-500 \mathrm{mdpl}$ dan morfometri $8^{\circ}$ sampai $>55^{\circ}$. Morfostruktur aktif merupakan aktivitas tektonik yang berlangsung relatif menerus sejak Eosen - Miosen Awal sampai Kuarter sehingga menjadikannya kawasan rawan bencana gempa bumi tinggi yang dapat menjadi faktor pemicu terjadinya longsor. Pengaruh tersebut menghasilkan pembentukan tatanan geologi diantaranya satuan litologi terobosan Diorit Bone $(T m b)$ dan Batuan Gunungapi Pinogu ( $T Q p v)$ dengan sistem kekar yang menjadikan proses pelapukan berjalan intensif pada tubuh batuan. Kondisi pelapukan batuan merupakan keadaan morfostruktur pasif suatu bentang lahan yang dapat mempengaruhi kekompakan batuan sehingga beberapa jenis diantaranya menjadi bahan longsoran jenis rock fall. Dari segi morfoaransemen daerah penelitian, adanya pengunaan lahan seperti pertanian lahan kering dan semak belukar hingga jalur transportasi darat dan permukiman, menjadikan daerah tersebut tidak hanya rawan terhadap longsor tetapi juga menjadi rentan menjadi sebuah bencana yang merugikan khususnya pada pembangunan berkelanjutan di Gorontalo.
\end{abstract}

Kata kunci: geomorfologi, sig, pembangunan berkelanjutan, leato, longsor rockfall

\begin{abstract}
Indonesia's sustainable development system should be disaster-based mitigation. This research aims to analyze spatial geomorphology aspects, that identifies the potential and vulnerability of disaster that can be caused in Leato area (North Leato and southern Leato) at District Dumbo Raya of Gorontalo. Geomorphologically studied aspects using Geographic Information System (GIS) Global Mapper v12 and ArcGIS v10.3. Geomorphological analysis at the location of the research found that the area has coastal morphography up to the steep hills with an average height of 200-500 mdpl and morphometry of $8^{\circ}$ to $>55^{\circ}$. Active morphostructure of tectonic activity which lasted relatively continuously since the Eocene - Early Miocene to Quarter, thus making it prone to high earthquake disaster that could become the trigger factor of a landslide. These influences resulted in the formation of geological structures including lithology breakthrough units Diorite Bone (Tmb) and Volcanic rocks Pinogu (TQpv) with a sturdy system that makes the weathering process run intensively on the body of the rock. Rock weathering conditions is a passive morphostructure of a landscape that can affect the cohesiveness of rocks so that some of them become rock fall type material avalanches. In terms of the morphology of the research area, the closure and use of land such as dryland and shrub farming to land and residential land transportation routes make the area not only vulnerable to landslides but also becomes vulnerable to a particularly adverse disaster on sustainable development in Gorontalo.
\end{abstract}

Keyword: geomorphology, gis, sustainable development, leato, rock fall landslides 


\section{PENDAHULUAN}

Pengaturan tentang penataan ruang di Indonesia harus berbasis mitigasi bencana telah diatur pada Undang-Undang No. 26 Tahun 2007. Hal ini merupakan upaya dalam mendukung pembangunan berkelanjutan yang dengan serta meningkatkan keselamatan dan kenyamanan kehidupan dan penghidupan masyarakat. Peristiwa bencana selain dapat menelan korban jiwa dan merugikan secara materi, juga akan berdampak langsung pada pembangunan berkelanjutan yang menguasai hajat hidup orang banyak di suatu daerah. Di Indonesia sendiri terdapat beberapa wilayah yang sedang menggiatkan pembangunan berkelanjutan di daerahnya. Salah satunya adalah Provinsi Gorontalo yang merupakan sebuah wilayah administratif baru hasil pemekaran dari Provinsi Sulawesi Utara sejak tahun 2001.

Dalam mendukung pengembangan wilayahnya, maka rencana pembangunan secara berkelanjutan haruslah berbasis mitigasi bencana. Salah satu daerah yang memiliki peran penting dan strategis dalam pembangunan Provinsi Gorontalo adalah daerah Leato (Kelurahan Leato utara dan Leato selatan) yang terletak pada Kecamatan Dumbo Raya Kotamadya Gorontalo. Letaknya di sebelah selatan Propinsi Gorontalo yang berbatasan langsung dengan pesisir Teluk Tomini, merupakan jalur Trans Propinsi dengan Sulawesi Utara, dan juga menjadi akses menuju ke beberapa tempat wisata dan kawasan pelabuhan kapal penumpang dan barang. Selain menjadi daerah yang memiliki peran penting dan strategis, Leato juga merupakan daerah dengan potensi longsor jenis jatuhan batu (rock falls) (Hutagalung, 2013). Diketahui daerah Leato memiliki morfologi berlereng terjal dengan kemiringan lereng $>65^{\circ}$ yang secara geologi regional terdiri dari batuan gunungapi pinogu (TQpv), Diorit Bone $(T m b)$ dan batugamping terumbu (QD) (Apandi dan Bachri, 1997).

Demi kemajuan suatu daerah, Rencana Tata Ruang Wilayah (RTRW) seharusnya tidak hanya difokuskan pada kebutuhan pembangunan saja, tapi juga memperhatikan aspek kemungkinan bencana yang akan terjadi. Pembangunan berkelanjutan mestinya berlandaskan pada konsep manajemen bencana yaitu tahap pengurangan risiko (kesiapsiagaan, mitigasi, pencegahan) dan tahap pemulihan atau penanganan pasca bencana (tanggap darurat, pemulihan, pembangunan kembali). Mengingat kondisi daerah Leato yang memiliki potensi bencana longsor, tetapi juga memiliki peran penting dan strategis dalam mendukung pembangunan berkelanjutan di Gorontalo, maka perlu dilakukan sebuah studi mengenai aspek-aspek geomorfologi kebencanaan pada daerah tersebut (Gambar 1).

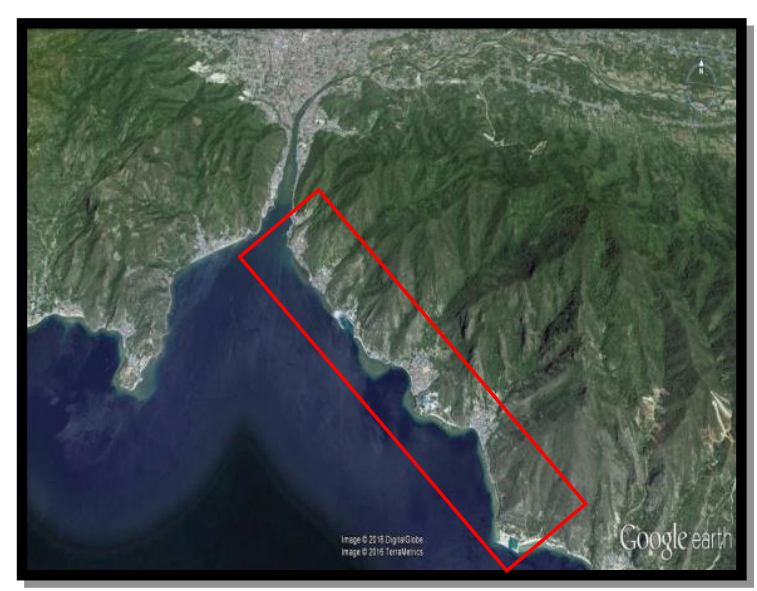

Gambar 1. Lokasi penelitian

Aspek-aspek geomorfologi dapat menjadi faktor pengontrol dan pemicu terjadinya bencana longsor, sehingga dapat menghambat proses pembangunan berkelanjutan. Sehingga dengan adanya hasil dari penelitian ini, diharapkan bisa menjadi acuan rencana pengembangan dan konsep pembangunan berkelanjutan yang sistematis dengan pengaturan dan pengelolaan yang baik (Widjaja, 2014). Studi pada aspek-aspek geomorfologi kebencanaan merupakan sebuah kajian kondisi daerah yang berbasis analisis spasial yang didukung dengan pengamatan langsung lapangan dan informasi historis bencana daerahnya. Aspek-aspek geomorfologi yang dimaksudkan dalam penelitian ini diantaranya adalah: morfografi, morfometri, morfostruktur aktif, morfostruktur pasif dan morfoaransemen. 


\section{METODE PENELITIAN}

Penelitian ini akan dilakukan dengan tahap pengolahan data berbasis spasial yang akan didukung secara realibilitas dengan pengamatan lapangan menurut informasi historis kebencanaan longsor dari masyarakat setempat. Informasi historis dikumpulkan secara manual, yaitu melalui wawancara langsung kepada masyarakat setempat mengenai titik-titik lokasi yang pernah mengalami longsor. Informasi lokasi historis longsor berupa deskripsi jenis litologi, bentuk lahan, kemiringan lereng, juga dampak yang ditimbulkan beserta dengan foto dan koordinat geografisnya. Pengamatan langsung di lapangan berupa kondisi geomorfologi daerah penelitian diantaranya aspek morfografi dan morfometri, morfostruktur aktif, morfostruktur pasif dan morfoaransemen.

Dalam menguji reliabilitas informasi yang didapatkan dilapangan, akan dilakukan pengolahan data vektor yang bersumber dari Peta Geologi lembar Kotamobagu (Apandi dan Bachri,1997) sebagai bahan analisa aspek morfostruktur-pasif, peta kawasan rawan bencana gempa bumi Provinsi Gorontalo (Rahayu, dkk., 2014) sebagai bahan analisa aspek morfostruktur-aktif dan peta Penutupan Lahan Provinsi Gorontalo (Pemprov Gorontalo, 2010-2030) sebagai bahan analisa aspek morfoaransemen. Sedang data raster daerah penelitian yang digunakan adalah data elevasi yang bersumber dari Advanced Spaceborn Thermal Emission and Reflection (ASTER) Global Digital Elevation Model (GDEM) v2 resolusi 30 meter yang bersumber dari NASA Jet Propulsion Laboratory (https://asterweb.jpl.nasa.gov/gdem.asp) yang digunakan sebagai bahan analisa aspek morfografi dan morfometri daerah penelitian. Hasil pengolahan dan analisa data-data spasial tersebut selanjutnya dideskripsikan menurut peran dan pengaruhnya terhadap bencana longsor yang berpotensi terjadi, serta kerentanan yang dapat ditimbulkan sebagai dampak kejadian tersebut, yaitu diantaranya seperti gangguan kehidupan dan penghidupan masyarakat juga pembangunan berkelanjutan suatu daerah. Keseluruhan data spasial tersebut diolah dengan perangkat lunak Sistem Informasi Geografis (SIG) yaitu Global Mapper v12 dan ArcGIS v10.3 ESRI.

\section{HASIL PENELITIAN}

\section{Aspek Morfografi dan Morfometri}

Morfografi daerah penelitian memiliki bentuk lahan dari pesisir Teluk Tomini hingga perbukitan dengan interval elevasi permukaannya berkisar antara 0 hingga $>500$ meter di atas permukaan laut (mdpl) (Gambar 2). Lahan dengan Morfometri umumnya antara $8^{\circ}-35^{\circ}$ dan pada beberapa titik lokasi memiliki kelerengan $>55^{\circ}$ (Gambar 3$)$.

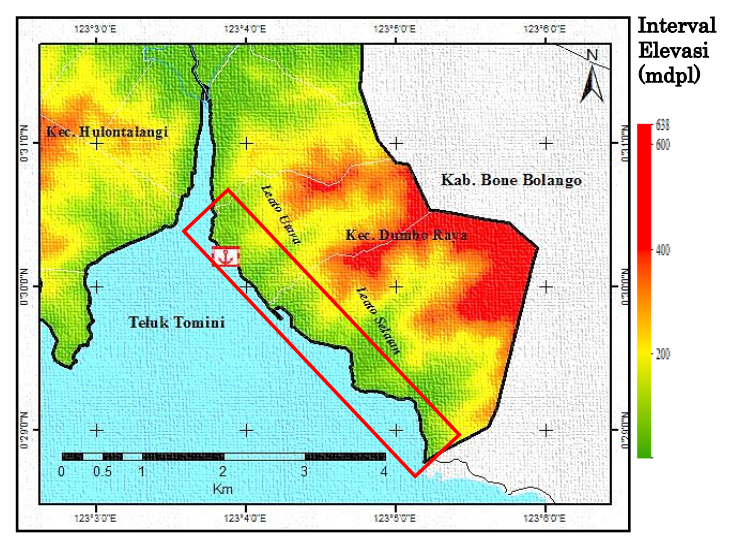

Gambar 2. Morfografi Leato

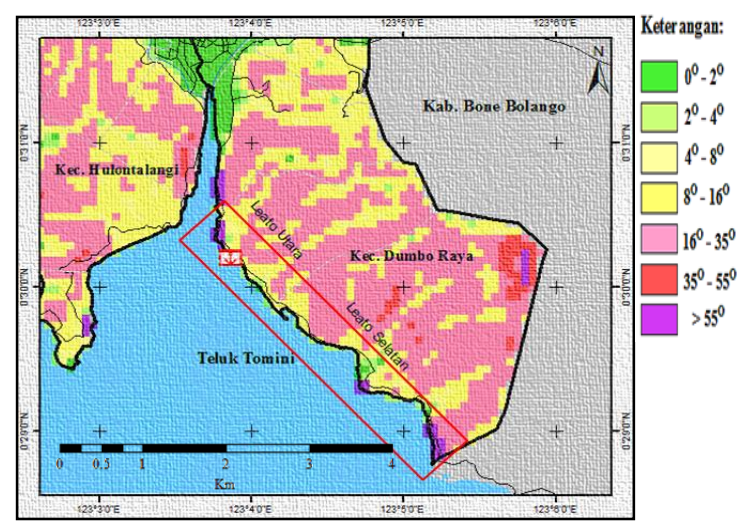

Gambar 3. Morfometri Leato

Mengacu pada klasifikasi hubungan sifat-sifat proses, karakteristik dan kondisi suatu lahan (Van Zuidam, 1985), maka hubungan morfografi dengan kelerengan lahan yang terdapat di daerah penelitian dapat dikategorikan curam hingga terjal, 
sering terjadi erosi permukaan dan erosi alur serta gerakan tanah sehingga merupakan daerah yang rawan terhadap bahaya erosi dan longsor. Dapat dikatakan bahwa aspek morfografi (topografi) dan morfometri (kemiringan lereng) merupakan faktor yang berperan sebagai pengontrol dalam terjadinya peristiwa longsor. Semakin besar kelerengan pada suatu lahan, akan semakin berpotensi mengalami longsor.

\section{Aspek Morfostruktur - Aktif}

Faktor alam yang berperan sebagai pemicu dalam peristiwa longsor diantaranya adalah aktifitas tektonik (gempa bumi), aktifitas vulkanik (erupsi gunung api) serta curah hujan yang tinggi. Kondisi morfologi di lapangan yang secara umum didominasi oleh perbukitan dengan tebing batu berlereng terjal, sangat berpotensi longsor lebih besar oleh akibat oleh getaran yang sangat kuat atau dalam hal ini aktifitas tektonik (gempa bumi). Secara umum lokasi penelitian merupakan kawasan rawan bencana gempa bumi tinggi (Gambar 4). Hal ini juga dapat menjadi indikasi bahwa potensi akan peristiwa bencana longsor jenis rockfall juga menjadi sangat tinggi.

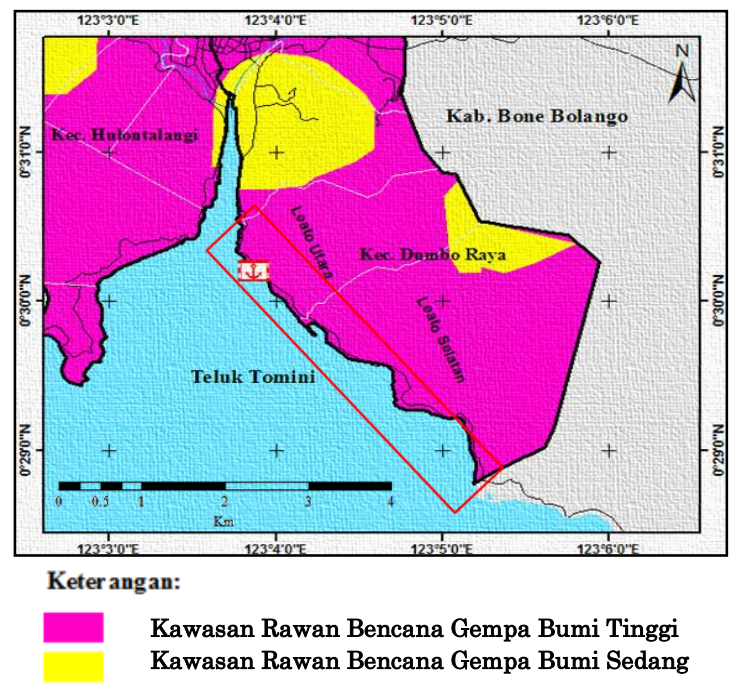

Gambar 4. Morfostruktur Aktif Leato

3. Aspek Morfostruktur - Pasif

Morfostruktur (pasif) yaitu mendeskripsikan tentang dinamika struktur kulit bumi dan lithologi/jenis batuan yang dihubungkan dengan proses endogenik yang terjadi terhadapnya, seperti proses pelarutan ataupun pelapukan (denudasional). Satuan batuan daerah penelitian (Gambar 5) berdasarkan Peta Geologi Lembar Kotamobagu didominasi oleh satuan Diorit Bone $(T m b)$ dan Batuan Gunungapi Pinogu (TQpv) (Apandi dan Bachri, 1997). Adapun yang tersingkap pada pengamatan lapangan diantaranya adalah batuan terobosan granit yang termasuk satuan Diorit Bone $(T m b)$, tuff lapili dan breksi vulkanik termasuk batuan G. api pinogu (TQpv), hingga setempat jenis gamping terumbu (coral) yang juga merupakan batuan terobosan.

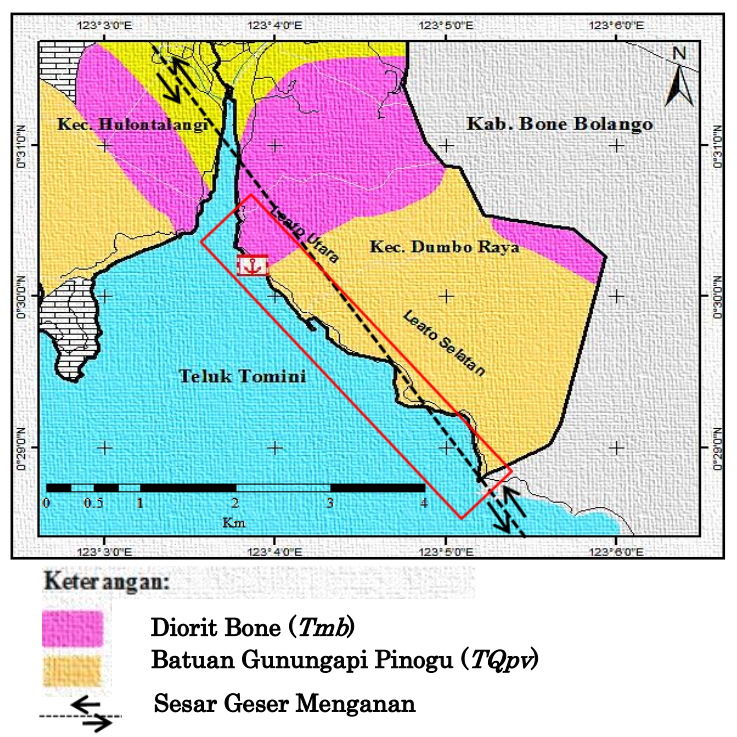

Gambar 5. Morfostruktur Pasif Leato

4. Aspek Morfoaransemen

Aspek morfoaransemen merupakan segala faktor yang mempengaruhi perubahan bentang lahan di atas permukaan bumi. Perubahan atas penutupan bentang lahan tidak lepas kaitannya terhadap penggunaan lahan yang terjadi terhadapnya. Tutupan lahan maupun juga tata guna lahan yang tidak tepat penggunaanya pada suatu daerah merupakan faktor risiko kerentanan atas dampak bencana yang dapat menimpa masyarakat. Pada Gambar 6 berikut adalah merupakan kondisi penutupan lahan dan penggunaannya di daerah penelitian yang diantaranya mencakup pertanian lahan kering dan semak belukar hingga 
permukiman juga jalur transportasi Trans Sulawesi. Kondisi penutupan lahan dan penggunaan lahan di daerah penelitian menjadikannya sangat berpotensi terhadap peristiwa longsor hingga memiliki nilai kerentanan tinggi terhadap pengguna jalan, kehidupan masyarakat hingga pembangunan berkelanjutan.

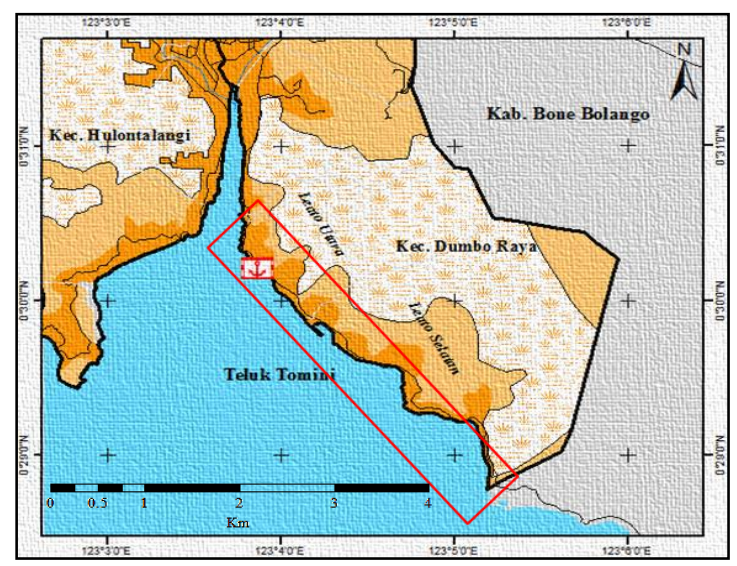

Keter angan:

Pertanian lahan kering \& Semak

Semak/Belukar

Permukiman

Gambar 6. Morfoaransemen Leato

\section{KESIMPULAN}

Analisa geomorfologi di lokasi penelitian didapatkan bahwa pada daerah Leato (Leato utara dan selatan) memiliki morfografi wilayah pesisir dan perbukitan terjal memiliki ketinggian rata-rata 200 $500 \mathrm{mdpl}$ dengan morfometri $8^{\circ}$ sampai $>55^{\circ}$. Perbukitan berlereng terjal yang terdapat di lokasi penelitian merupakan suatu runtunan regresif akibat aktivitas tektonik yang berlangsung relatif menerus sejak Eosen Miosen Awal sampai Kuarter. Dari aspek morfostruktur aktif, hal inilah yang menjadikan daerah penelitian merupakan kawasan rawan bencana gempa bumi tinggi hingga dapat menjadi faktor pemicu peristiwa gerakan tanah dan batuan (rock fall).

Dari aspek morfostruktur pasif, hasil aktivitas tektonik tersebut menghasilkan tatanan geologi dengan beragam jenis litologi yang tersingkap di lapangan dan dalam Peta Geologi Lembar Kotamobagu, diantaranya adalah granit (Diorit Bone (Tmb)), tuf lapili dan breksi (Batuan Gunungapi Pinogu (TQpv)) serta gamping terumbu yang merupakan batuan terobosan. Jika berdasarkan informasi historis peristiwa longsor di daerah penelitian, diketahui bahwa batu granit dan tuf lapili adalah merupakan bahan longsoran jenis rock fall yang paling sering terjadi. Aspek morfoaransemen pada daerah penelitian, yaitu adanya penutupan dan penggunaan lahan seperti pertanian lahan kering dan semak belukar hingga jalur transportasi darat dan permukiman, menjadikan daerah penelitian tidak hanya rawan terhadap longsor tetapi juga menjadi rentan menjadi sebuah bencana yang merugikan khususnya pada pembangunan berkelanjutan di Gorontalo.

\section{UCAPAN TERIMAKASIH}

Tim penulis mengucapkan Terima Kasih atas dukungan dan bantuan penelitian ini kepada:

1) DRPM Ristekdikti

2) LPPM Universitas Muhammadiyah Gorontalo

3) Rekan - rekan Civitas Akademika Universitas Muhammadiyah Gorontalo 


\section{PUSTAKA}

Apandi, T dan Bachri, S., 1997. Peta Geologi Lembar Kotamobagu, Sulawesi, skala 1:250.000. Pusat Penelitian dan Pengembangan Geologi. Bandung.

Badan Pusat Statistik (BPS), 2016. Kecamatan Dumbo Raya Dalam Angka 2016, Gorontalo

Hutagalung, R., 2013. Kontrol Litologi Terhadap Bencana Gerakan Tanah Di Daerah Leato Provinsi Gorontalo. Tesis pada Program studi Teknik Geologi, Fakultas Teknik, Universitas Hasanuddin. Makassar.

National Aeronautics and Space Adinistration (NASA). Advanced Spaceborn Thermal Emission and Reflection (ASTER) Global Digital Elevation Model (GDEM) v2 from Jet Propulsion Laboratory https://asterweb.jpl.nasa.gov/gdem.asp/ [diakses pada 8 Oktober 2017]

Provinsi Gorontalo., 2010. Peta Penutupan Lahan Provinsi Gorontalo, skala 1:250.000. Rencana Tata Ruang Wilayah Provinsi Gorontao Tahun 2010-2030. Pemerintah Provinsi Gorontalo. Gorontalo.

Rahayu, R., Cipta, A., Griffin, J., Hoorspol, N., 2014. Peta Kawasan Rawan Bencana Gempa Bumi Provinsi Gorontalo, skala 1:500.000. Pusat Vulkanologi dan Mitigasi Bencan Geologi. Bandung

Republik Indonesia., 2007. Undang-Undang No. 26 Tahun 2007 Tentang Penataan Ruang.

Sompotan, A.F. 2012. Struktur Geologi Sulawesi. Perpustakaan Sains Kebumian. Institut Teknologi Bandung. Bandung.
Widjaja, B.W., 2014. Bekerja Dengan Hati Untuk Hasil Masterpiece. Deputi Bidang Rehabilitasi dan Rekonstruksi BNPB. GEMA BNPB Volume 5 No.2 ISSN 2088-6527, hal.61-67.

Van Zuidam, R.A., 1985. Aerial PhotoInterpretation in Terrain Analysis and Geomorphologic Mapping. Smith Publisher, The Hague, ITC. 